\title{
Gordonia humi sp. nov., isolated from soil
}

\author{
Correspondence \\ P. Kämpfer \\ peter.kaempfer@umwelt.uni- \\ giessen.de \\ P. D. Rekha \\ rekhapd@hotmail.com
}

\section{P. Kämpfer, ${ }^{1}$ Chiu-Chung Young, ${ }^{2}$ Jiunn-Nan Chu, ${ }^{2}$ A. Frischmann, ${ }^{3}$ H.-J. Busse, ${ }^{3}$ A. B. Arun, ${ }^{4}$ Fo-Ting Shen ${ }^{2}$ and P. D. Rekha ${ }^{4}$}

\author{
${ }^{1}$ Institut für Angewandte Mikrobiologie, Justus-Liebig-Universität Giessen, D-35392 Giessen, \\ Germany \\ ${ }^{2}$ College of Agriculture and Natural Resources, Department of Soil \& Environmental Sciences, \\ National Chung Hsing University, Taichung 402, Taiwan, ROC \\ ${ }^{3}$ Institut für Bakteriologie, Mykologie und Hygiene, Veterinärmedizinische Universität, A-1210 Wien, \\ Austria \\ ${ }^{4}$ Yenepoya Research Center, Yenepoya University, University Road, Deralakatte, Mangalore 575 \\ 018, Karnataka, India
}

A Gram-stain-positive, non-endospore-forming actinobacterium $\left(\mathrm{CC}-12301^{\top}\right)$ was isolated from soil attached to a spawn used in the laboratory to grow the edible mushroom Agaricus brasiliensis. Based on $16 \mathrm{~S}$ rRNA gene sequence similarities, strain CC- $12301^{\top}$ was shown to belong to the genus Gordonia and was most closely related to the type strains of Gordonia hydrophobica (97.6\% similarity), Gordonia terrae (97.5\%), Gordonia amarae (97.5\%) and Gordonia malaquae (97.4\%). The quinone system was determined to consist predominantly of menaquinone MK- $9\left(\mathrm{H}_{2}\right)$, minor amounts of $\mathrm{MK}-8\left(\mathrm{H}_{2}\right)$ and $\mathrm{MK}-7\left(\mathrm{H}_{2}\right)$. The polar lipid profile consisted of the major compounds diphosphatidylglycerol and phosphatidylethanolamine, moderate amounts of two phosphatidylinositol mannosides and phosphatidylinositol and minor amounts of phosphatidylglycerol, three unidentified glycolipids, two phosphoglycolipids and a phospholipid. Mycolic acids were present. These chemotaxonomic traits and the major fatty acids, which were $\mathrm{C}_{16: 1}$ cis $9, \mathrm{C}_{16: 0}, \mathrm{C}_{18: 1}$ and tuberculostearic acid (10-methyl $\mathrm{C}_{18: 0}$ ), supported the affiliation of strain $\mathrm{CC}-12301^{\top}$ to the genus Gordonia. The results of physiological and biochemical tests allowed clear phenotypic differentiation of strain CC-12301 ${ }^{\top}$ from the most closely related Gordonia species. Strain CC- $12301^{\top}$ therefore represents a novel species, for which the name Gordonia humi sp. nov. is proposed, with the type strain CC- $12301^{\top}$ (=DSM $45298^{\top}=$ CCM $7727^{\top}$ ).
The genus Gordonia (originally 'Gordona') was initially proposed by Tsukamura (1971), and strains of this genus belong to the mycolic acid-containing group of the actinomycetes and to the suborder Corynebacterineae, which forms a distinct phylogenetic lineage in the $16 \mathrm{~S}$ rRNA gene tree (Goodfellow et al., 1998; Stackebrandt et al., 1997). At the time of writing, the genus Gordonia comprises 29 species, Gordonia bronchialis (the type species), G. rubripertincta, G. sputi and G. terrae (Stackebrandt et al., 1988), G. aichiensis and G. amarae (Klatte et al., 1994), G. hydrophobica (Bendinger et al., 1995), G. hirsuta (Klatte et al., 1996), G. rhizosphera (Takeuchi \& Hatano, 1998), G. desulfuricans (Kim et al., 1999), G. alkanivorans (Kummer et al., 1999) [according to

The GenBank/EMBL/DDBJ accession number for the 16S rRNA gene sequence of strain CC-12301' is FN561544.

A supplementary table and two supplementary figures are available with the online version of this paper.
Arenskötter et al. (2005), G. alkanivorans is an earlier heterotypic synonym of Gordonia nitida Yoon et al. 2000], G. polyisoprenivorans (Linos et al., 1999), G. amicalis (Kim et al., 2000), G. namibiensis (Brandão et al., 2001), G. westfalica (Linos et al., 2002), G. sihwensis (Kim et al., 2003), G. sinesedis (Maldonado et al., 2003), G. paraffinivorans (Xue et al., 2003), G. otitidis (Iida et al., 2005), G. araii and G. effusa (Kageyama et al., 2006), G. soli (Shen et al., 2006), G. defluvii (Soddell et al., 2006), G. shandongensis (Luo et al., 2007), G. malaquae (Yassin et al., 2007), G. lacunae (Le Roes et al., 2008) and G. cholesterolivorans (Drzyzga et al., 2009). Members of the genus Gordonia were originally reported to be opportunistic pathogens that were isolated from various clinical material such as sputum of humans suffering from pulmonary diseases, e.g. G. bronchialis, G. aichiensis and G. sputi (Kim et al., 2003), but, more recently, many Gordonia isolates have been isolated from various environmental sources and some of them have been reported to be involved 
in the degradation of xenobiotic compounds, such as benzothiophene and dibenzothiophene by G. desulfuricans and G. amicalis (Kim et al., 1999, 2000) and alkanes by G. alkanivorans (Kummer et al., 1999).

Strain CC- $12301^{\mathrm{T}}$ was isolated from soil attached to a spawn used in the laboratory for growing the edible mushroom Agaricus brasiliensis and was maintained on nutrient agar (NA; Oxoid) after incubation at $30{ }^{\circ} \mathrm{C}$ for $48 \mathrm{~h}$. The strain was preserved at $-80{ }^{\circ} \mathrm{C}$ in nutrient broth (NB; Oxoid) with $20 \%$ (v/v) glycerol or by lyophilization.

Morphological properties, Gram-staining and cell morphology were observed by phase-contrast microscopy as described by Kämpfer \& Kroppenstedt (2004).

The 16S rRNA gene sequence of strain CC- $12301^{\mathrm{T}}$ was determined and analysed as described previously (Kämpfer \& Kroppenstedt, 2004). The $16 \mathrm{~S}$ rRNA gene sequence of strain CC- $12301^{\mathrm{T}}$ was a continuous stretch of $1438 \mathrm{bp}$. Multiple sequence alignment and analysis of the data were performed using the software package MEGA version 4 (Tamura et al. 2007) as well as with the ARB software package (version December 2007; Ludwig et al., 2004) and the corresponding SILVA SSURef 95 database (release July 2008; Pruesse et al., 2007). Genetic distances were calculated on the basis of pairwise comparisons using the ARB program and clustering was performed with the neighbour-joining (Supplementary Fig. S1, available in IJSEM Online) and maximum-parsimony (results not shown) methods using MEGA 4 and bootstrap values based on 1000 replications. Tree reconstruction using the maximum-likelihood method with fastDNAml (Olsen et al., 1994) was performed with the ARB software package (Fig. 1). Tree topology was further tested without filters. Several differences could be observed between these trees. Sequence similarity calculations on the basis of a pairwise comparison indicated that the closest relatives of strain CC- $12301^{\mathrm{T}}$ were the type strains of $G$. hydrophobica $(97.6 \%)$, G. terrae $(97.5 \%)$, G. amarae $(97.5 \%)$ and G. malaquae (97.4\%). Type strains of other Gordonia species revealed 16S rRNA gene sequence similarities $<97.4 \%$. Almost the same values were obtained for pairwise similarity calculations based on the algorithm of the EzTaxon program (Chun et al., 2007). These similarities were not reflected in the trees. However, the close relationship of strain CC- $12301^{\mathrm{T}}$ to G. hydrophobica is clearly shown in Fig. 1, and the cluster of G. hydrophobica, G. sihwensis, G. cholesterolivorans, G. paraffinivorans, G. hirsuta and G. shandongensis shown in Fig. 1 was also reported by Drzyzga et al. (2009). From other studies (e.g. Soddell et al., 2006; Yassin et al., 2007), it is clear that many Gordonia clusters are not stable and that relationships are not supported by high bootstrap values. If the results obtained with different treeing algorithms disagree, the closest relatives of a given sequence are identified on the basis of individual sequence similarities. It has been shown previously that members of distinct Gordonia species can show relatively high $16 \mathrm{~S}$ rRNA gene sequence similarity, e.g. the type strains of G. bronchialis and G. terrae share $98.3 \%$ similarity, which corresponds to 25 nucleotide differences, while members of these species show DNA-DNA relatedness within the range 16-21\% (Zakrzewska-Czerwinska et al., 1988). A similar result was obtained for the type strains of $G$.

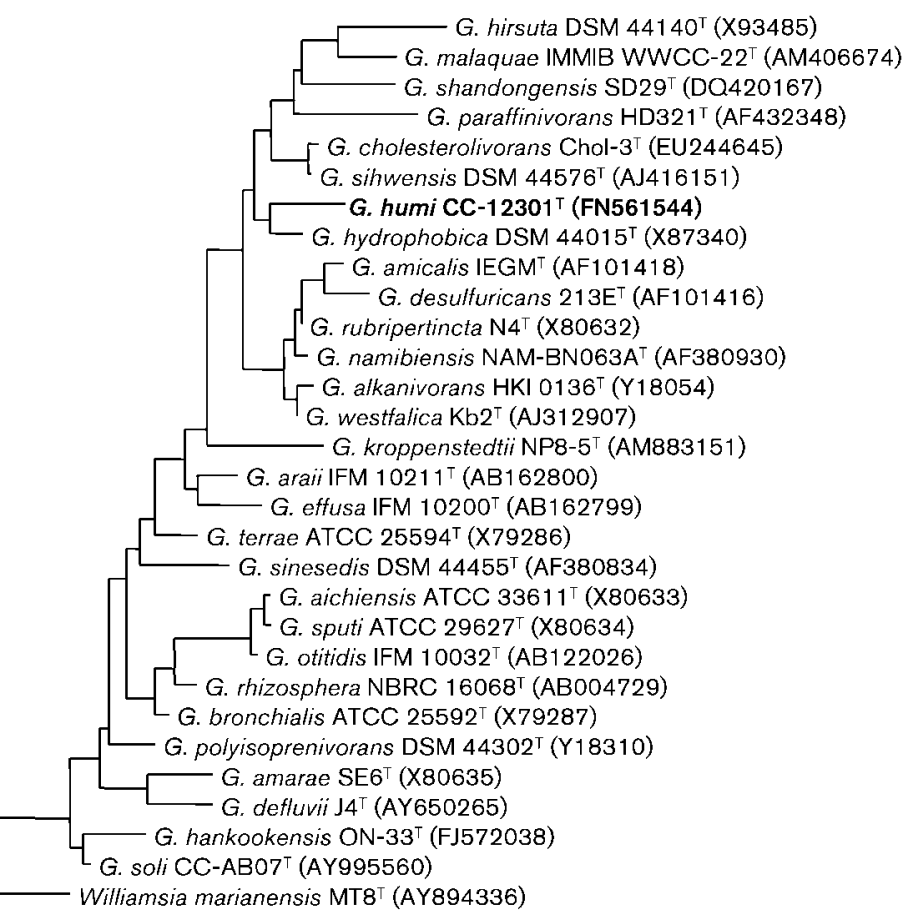

0.10
Fig. 1. Phylogenetic analysis based on $16 \mathrm{~S}$ rRNA gene sequences available from the European Molecular Biology Laboratory database (accession numbers in parentheses). The phylogenetic tree was constructed using the ARB software package (version December 2007; Ludwig et al., 2004) and the corresponding SILVA SSURef 95 database (release July 2008; Pruesse et al., 2007). Tree building was performed using the maximum-likelihood method with fastDNAml (Olsen et al., 1994). Bar, 0.10 substitutions per nucleotide position. 
aichiensis and G. sputi, sharing $99.7 \%$ 16S rRNA gene nucleotide similarity and 38-40\% DNA-DNA relatedness (Goodfellow et al., 1998; Klatte et al., 1994). For this reason, only the type strains of the most closely related species ( $G$. hydrophobica, G. terrae and G. amarae) were included in DNA-DNA hybridization experiments.

For mycolic acid, quinone and polar lipid analyses, cells were grown on PYE medium $(0.3 \%$ yeast extract, $0.3 \%$ peptone from casein, $\mathrm{pH}$ 7.2). Quinones and polar lipids were extracted and analysed as described by Tindall (1990a, b) and Altenburger et al. (1996). HPLC analysis of quinones was carried out using the equipment reported by Stolz et al. (2007). Mycolic acids were extracted according to Minnikin et al. (1975), spotted on silica gel 60 thin-layer glass sheets (Merck 105626), developed in chloroform/methanol/water $(65: 25: 4$, by vol.) and detected by charring at $140{ }^{\circ} \mathrm{C}$ after spraying with ethanolic molybdatophosphoric acid $(5 \%, \mathrm{w} / \mathrm{v})$.

Table 1. Physiological properties of Gordonia humi sp. nov. CC-12301 ${ }^{\top}$ and related type strains of the genus Gordonia

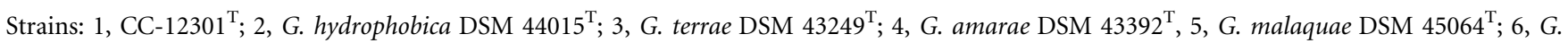
sihwensis SPR2 $2^{\mathrm{T}}$; 7, G. aichiensis DSM 43978 ${ }^{\mathrm{T}}$; 8, G. alkanivorans DSM 44369 ${ }^{\mathrm{T}}$; 9, G. amicalis DSM 44461 ${ }^{\mathrm{T}}$; 10, G. bronchialis DSM $43247^{\mathrm{T}}$; 11 , G. desulfuricans DSM $44462^{\mathrm{T}} ; 12$, G. hirsuta DSM $44140^{\mathrm{T}} ; 13$, G. namibiensis DSM 44568 ${ }^{\mathrm{T}}$; 14, G. nitida DSM 44499 ${ }^{\mathrm{T}}$; 15, G. polyisoprenivorans DSM $44302^{\mathrm{T}}$; 16, G. rhizosphera NBRC $16068^{\mathrm{T}}$; 17, G. rubripertincta DSM $43197^{\mathrm{T}}$; 18, G. sputi DSM 43896 ${ }^{\mathrm{T}}$; 19, G. westfalica DSM $44215^{\mathrm{T}}$. Data for reference strains were taken from Linos et al. (1999) (columns 2-4, 7, 16, 18 and 19), Yassin et al. (2007) (column 5) and Kim et al. (2003) (columns 6, 8-15 and 17); with the exception of the data for G. malaquae DSM $45064^{\mathrm{T}}$, the table is based on the compilation of Kim et al. (2003), using the same methods used for characterization of strain CC- $12301^{\mathrm{T}}$. ND, No data available; $p$-NP, $p$-nitrophenyl.

\begin{tabular}{|c|c|c|c|c|c|c|c|c|c|c|c|c|c|c|c|c|c|c|c|}
\hline Characteristic & 1 & 2 & 3 & 4 & 5 & 6 & 7 & 8 & 9 & 10 & 11 & 12 & 13 & 14 & 15 & 16 & 17 & 18 & 19 \\
\hline \multicolumn{20}{|l|}{ Utilization of: } \\
\hline D-Galactose & - & $+^{*}$ & $+^{*}$ & $+^{*}$ & - & + & + & + & + & + & + & + & + & + & + & + & + & + & - \\
\hline D-Ribose & - & $+^{*}$ & $-^{*}$ & $+^{*}$ & $\mathrm{ND}$ & - & - & + & + & - & + & - & + & + & - & - & + & - & + \\
\hline Sucrose & + & $+^{*}$ & $+^{*}$ & $+^{*}$ & + & + & - & + & + & + & + & - & + & + & + & + & + & - & + \\
\hline Turanose & - & - & - & + & $\mathrm{ND}$ & + & - & + & + & + & + & - & - & + & + & + & - & - & - \\
\hline myo-Inositol & - & $+\dagger$ & $-*$ & $-{ }^{\star}$ & - & - & - & + & - & + & - & + & - & + & + & + & - & - & - \\
\hline $\mathrm{N}$-Acetyl-D-glucosamine & + & $-{ }^{\star}$ & $-{ }^{*}$ & $-{ }^{*}$ & $\mathrm{ND}$ & + & - & + & - & + & + & - & - & - & + & + & - & - & - \\
\hline Glucarate & - & + & + & - & $\mathrm{ND}$ & - & - & + & + & - & - & - & - & + & - & - & + & - & - \\
\hline Gluconate & - & $-{ }^{*}$ & $-*$ & $-\dagger$ & $\mathrm{ND}$ & + & - & + & + & + & + & - & + & + & + & + & + & - & - \\
\hline Caprate & - & - & - & $\mathrm{ND}$ & $\mathrm{ND}$ & + & + & + & + & + & + & ND & - & - & $\mathrm{ND}$ & - & - & + & + \\
\hline Citrate & + & $+^{*}$ & $+^{*}$ & $+^{*}$ & + & + & + & + & + & - & + & - & - & + & + & + & - & + & + \\
\hline 3-Hydroxybenzoate & + & - & - & - & - & - & - & + & - & - & + & - & - & + & - & + & - & - & - \\
\hline 4-Hydroxybenzoate & - & $-*$ & $-{ }^{*}$ & $+^{*}$ & - & - & - & + & + & + & + & - & + & + & + & + & - & - & - \\
\hline Phenylacetate & - & $-*$ & $-{ }^{*}$ & $-{ }^{\star}$ & $\mathrm{ND}$ & + & - & + & + & + & + & - & - & + & - & - & + & - & - \\
\hline Quinate & - & - & - & + & ND & - & + & - & - & - & - & - & + & - & + & + & - & - & - \\
\hline L-Alanine & - & $+\dagger$ & $-*$ & $-*$ & + & - & + & + & + & + & + & - & + & + & + & - & + & - & - \\
\hline L-Aspartate & - & $-*$ & $-*$ & $-*$ & $\mathrm{ND}$ & - & + & + & + & - & - & - & - & + & + & - & - & - & + \\
\hline L-Leucine & - & $+^{\star}$ & $-^{*}$ & $-{ }^{*}$ & $\mathrm{ND}$ & + & - & + & + & + & + & - & - & - & - & - & - & - & - \\
\hline L-Proline & + & $+^{*}$ & $-^{*}$ & $+\dagger$ & + & + & - & + & - & - & + & - & - & - & + & - & - & - & - \\
\hline L-Serine & - & + & - & - & + & + & - & - & + & - & - & - & + & + & - & - & - & - & - \\
\hline L-Valine & - & + & - & + & $\mathrm{ND}$ & + & - & - & - & + & - & - & - & + & + & - & - & - & - \\
\hline Putrescine & - & $-{ }^{\star}$ & $-^{\star}$ & $+^{*}$ & $\mathrm{ND}$ & - & - & + & + & - & + & - & - & - & + & - & - & - & - \\
\hline
\end{tabular}

${ }^{*}$ Compared in this study and confirmed.

†Compared in this study but not confirmed.

\$Not reported by Linos et al. (1999); result from this study in parentheses. 
Mycolic acids were detected in the extract of strain CC$12301^{\mathrm{T}}$. The mycolic acid spot showed almost identical chromatographic behaviour to the mycolic acids of $G$. terrae DSM $43249^{\mathrm{T}}$ and G. hydrophobica DSM $44015^{\mathrm{T}}$, which were extracted and analysed concurrently (results not shown). The two reference strains were reported to contain mycolic acids containing predominantly 56-60 carbon atoms; hence, strain $\mathrm{CC}-12301^{\mathrm{T}}$ can also be considered to have mycolic acids of similar size. The quinone system consisted predominantly of menaquinone MK-9 $\left(\mathrm{H}_{2}\right)$, with minor amounts of $\mathrm{MK}-8\left(\mathrm{H}_{2}\right)$ and MK$7\left(\mathrm{H}_{2}\right)$, in the ratio $93.0: 6.5: 0.4$. The polar lipid profile was composed of the major compounds diphosphatidylglycerol and phosphatidylethanolamine. Furthermore, moderate amounts of two phosphatidylinositol mannosides and phosphatidylinositol and minor amounts of phosphatidylglycerol, three unidentified glycolipids, two phosphoglycolipids and a phospholipid were detected (Supplementary Fig. S2a). This profile clearly distinguished CC- $12301^{\mathrm{T}}$ from $G$. hydrophobica DSM $44015^{\mathrm{T}}$ and G. terrae DSM $43249^{\mathrm{T}}$, which were also examined (Supplementary Fig. $\mathrm{S} 2 \mathrm{~b}, \mathrm{c})$. In the two reference strains, none of the three unidentified glycolipids was detected, and the phosphatidylinositol mannoside that exhibited the same behaviour in the second chromatographic dimension as phosphatidylinositol was detected only in trace amounts in $G$. hydrophobica DSM $44015^{\mathrm{T}}$ and was not detectable in $G$. terrae DSM $43249^{\mathrm{T}}$.

Fatty acid analysis was performed according to Kämpfer \& Kroppenstedt (1996). The fatty acid profile of strain CC$12301^{\mathrm{T}}$ was similar to those of the other closely related type strains G. hydrophobica DSM $44015^{\mathrm{T}}$ and G. terrae DSM $43249^{\mathrm{T}}$ (Supplementary Table S1). It was composed mainly of the fatty acids $\mathrm{C}_{16: 1}$ cis $9, \mathrm{C}_{16: 0}, \mathrm{C}_{18: 1}$ and tuberculostearic acid (10-methyl $\left.\mathrm{C}_{18: 0}\right)$. Results from analysis of mycolic acids, quinones, polar lipids and fatty acids are in excellent agreement with the traits listed in the genus description (Stackebrandt et al., 1988) and, hence, support the affiliation of strain CC- $12301^{\mathrm{T}}$ to the genus Gordonia.

Results of the physiological characterization are given in Table 1 and the species description, with methods described previously (Kämpfer et al., 1991). The results show that strain CC- $12301^{\mathrm{T}}$ was clearly different from the most closely related Gordonia species.

As indicated above, DNA-DNA hybridization experiments were performed with CC- $12301^{\mathrm{T}}$ and the type strains $G$. hydrophobica DSM $44015^{\mathrm{T}}$, G. terrae ATCC $25594^{\mathrm{T}}$ and $G$. amarae DSM $43392^{\mathrm{T}}$ using the method described by Ziemke et al. (1998), with a minor variation in the nick translation step, where $2 \mu \mathrm{g}$ DNA was labelled over a $3 \mathrm{~h}$ incubation at $15{ }^{\circ} \mathrm{C}$.

We assumed a $\mathrm{G}+\mathrm{C}$ content of $67 \mathrm{~mol} \%$ for strain CC$12301^{\mathrm{T}}$ in the DNA-DNA hybridization experiments. Strain CC- $12301^{\mathrm{T}}$ showed relatively low DNA-DNA relatedness to G. hydrophobica DSM $44015^{\mathrm{T}}(27.7 \%$, reciprocal $25.5 \%)$, G. terrae ATCC $25594^{\mathrm{T}}$ (33.4\%, reciprocal $\left.34.7 \%\right)$ and $G$. amarae DSM $43392^{\mathrm{T}}(40.2 \%$, reciprocal $34.8 \%)$. The observed physiological differences between these type strains (Table 1) as well as the unique polar lipid profile clearly warrant the creation of a separate species.

\section{Description of Gordonia humi sp. nov.}

Gordonia humi (hu'mi. L. gen. n. humi of/from soil, the source of the type strain).

Coccoid cells, about 1.0-1.5 $\mu \mathrm{m}$ in diameter. Gram-stainpositive and oxidase- and catalase-positive, showing an aerobic respiratory metabolism. Good growth occurs after 3 days of incubation on TSA, R2A agar and nutrient agar at $25-30{ }^{\circ} \mathrm{C}$. The quinone system consists of the predominant compound menaquinone $\mathrm{MK}-9\left(\mathrm{H}_{2}\right)$ and minor amounts of $\mathrm{MK}-8\left(\mathrm{H}_{2}\right)$ and $\mathrm{MK}-7\left(\mathrm{H}_{2}\right)$. The polar lipid profile is composed of the major compounds diphosphatidylglycerol and phosphatidylethanolamine. Moderate amounts of two phosphatidylinositol mannosides and phosphatidylinositol and minor amounts of phosphatidylglycerol, three unidentified glycolipids, two phosphoglycolipids and a phospholipid are also present. Mycolic acids are present. Major fatty acids are $\mathrm{C}_{16: 1}$ cis 9 , $\mathrm{C}_{16: 0}, \mathrm{C}_{18: 1}$ and tuberculostearic acid (10-methyl $\mathrm{C}_{18: 0}$ ) (Supplementary Table S1). The type strain is able to utilize D-glucose, sucrose, $N$-acetyl-D-glucosamine, citrate and proline, but not D-galactose, L-rhamnose, D-ribose, turanose, D-adonitol, myo-inositol, caprate, 4-aminobutyrate, L-alanine, asparagine or L-leucine. Further details of carbon source utilization (including differentiating characters on the basis of identical test conditions) are indicated in Table 1.

The type strain is CC- $12301^{\mathrm{T}}\left(=\mathrm{DSM} 45298^{\mathrm{T}}=\mathrm{CCM}\right.$ $7727^{\mathrm{T}}$ ), which was isolated from a spawn used for growing the edible mushroom Agaricus brasiliensis.

\section{Acknowledgements}

We are grateful to Gundula Will for excellent technical assistance. This work was supported by the National Science Council, Taiwan ROC, and the Council of Agriculture, EY, Taiwan ROC.

\section{References}

Altenburger, P., Kämpfer, P., Makristathis, A., Lubitz, W. \& Busse, H.-J. (1996). Classification of bacteria isolated from a medieval wall painting. J Biotechnol 47, 39-52.

Arenskötter, M., Linos, A., Schumann, P., Kroppenstedt, R. M. \& Steinbüchel, A. (2005). Gordonia nitida Yoon et al. 2000 is a later synonym of Gordonia alkanivorans Kummer et al. 1999. Int J Syst Evol Microbiol 55, 695-697.

Bendinger, B., Rainey, F. A., Kroppenstedt, R. M., Moormann, M. \& Klatte, S. (1995). Gordona hydrophobica sp. nov., isolated from biofilters for waste gas treatment. Int J Syst Bacteriol 45, 544-548.

Brandão, P. F. B., Maldonado, L. A., Ward, A. C., Bull, A. T. \& Goodfellow, M. (2001). Gordonia namibiensis sp. nov., a novel nitrile metabolising actinomycete recovered from an African sand. Syst Appl Microbiol 24, 510-515. 
Chun, J., Lee, J.-H., Jung, H., Kim, M., Kim, S., Kim, B. K. \& Lim, Y. W. (2007). EzTaxon: a web-based tool for the identification of prokaryotes based on $16 \mathrm{~S}$ ribosomal RNA gene sequences. Int J Syst Evol Microbiol 57, 2259-2261.

Drzyzga, O., Navarro Llorens, J. M., Fernández de las Heras, L., Garcia Fernández, E. \& Perera, J. (2009). Gordonia cholesterolivorans sp. nov., a cholesterol-degrading actinomycete isolated from sewage sludge. Int J Syst Evol Microbiol 59, 1011-1015.

Goodfellow, M., Alderson, G. \& Chun, J. (1998). Rhodococcal systematics: problems and developments. Antonie van Leeuwenhoek 74, 1-12.

lida, S., Taniguchi, H., Kageyama, A., Yazawa, K., Chivana, H., Murata, S., Nomura, F., Kroppenstedt, R. M. \& Mikami, Y. (2005). Gordonia otitidis sp. nov., isolated from a patient with external otitis. Int J Syst Evol Microbiol 55, 1871-1876.

Kageyama, A., lida, S., Yazawa, K., Kudo, T., Suzuki, S., Koga, T., Saito, H., Inagawa, H., Wada, A. \& other authors (2006). Gordonia araii sp. nov. and Gordonia effusa sp. nov., isolated from patients in Japan. Int J Syst Evol Microbiol 56, 1817-1821.

Kämpfer, P. \& Kroppenstedt, R. M. (1996). Numerical analysis of fatty acid patterns of coryneform bacteria and related taxa. Can $J$ Microbiol 42, 989-1005.

Kämpfer, P. \& Kroppenstedt, R. M. (2004). Gordonia benzenivorans sp. nov. Int J Syst Evol Microbiol 54, 749-751.

Kämpfer, P., Steiof, M. \& Dott, W. (1991). Microbiological characterization of a fuel-oil contaminated site including numerical identification of heterotrophic water and soil bacteria. Microb Ecol 21, 227-251.

Kim, S. B., Brown, R., Oldfield, C., Gilbert, S. C. \& Goodfellow, M. (1999). Gordonia desulfuricans sp. nov., a benzothiophene-desulphurizing actinomycete. Int J Syst Bacteriol 49, 1845-1851.

Kim, S. B., Brown, R., Oldfield, C., Gilbert, S. C., lliarionov, S. \& Goodfellow, M. (2000). Gordonia amicalis sp. nov., a novel dibenzothiophene-desulphurizing actinomycete. Int $J$ Syst Evol Microbiol 50, 2031-2036.

Kim, K. K., Lee, C. S., Kroppenstedt, R. M., Stackebrandt, E. \& Lee, S. T. (2003). Gordonia sihwensis sp. nov., a novel nitrate-reducing bacterium isolated from a wastewater-treatment bioreactor. Int J Syst Evol Microbiol 53, 1427-1433.

Klatte, S., Rainey, F. A. \& Kroppenstedt, R. M. (1994). Transfer of Rhodococcus aichiensis Tsukamura 1982 and Nocardia amarae Lechevalier and Lechevalier 1974 to the genus Gordona as Gordona aichiensis comb. nov. and Gordona amarae comb. nov. Int J Syst Bacteriol 44, 769-773.

Klatte, S., Kroppenstedt, R. M., Schumann, P., Altendorf, K. \& Rainey, F. A. (1996). Gordona hirsuta sp. nov. Int J Syst Bacteriol 46, 876-880.

Kummer, C., Schumann, P. \& Stackebrandt, E. (1999). Gordonia alkanivorans sp. nov., isolated from tar-contaminated soil. Int J Syst Bacteriol 49, 1513-1522.

Le Roes, M., Goodwin, C. M. \& Meyers, P. R. (2008). Gordonia lacunae sp. nov., isolated from an estuary. Syst Appl Microbiol 31, 1723.

Linos, A., Steinbüchel, A., Spröer, C. \& Kroppenstedt, R. M. (1999). Gordonia polyisoprenivorans sp. nov., a rubber-degrading actinomycete isolated from an automobile tyre. Int J Syst Bacteriol 49, 17851791

Linos, A., Berekaa, M. M., Steinbüchel, A., Kim, K. K., Spröer, C. \& Kroppenstedt, R. M. (2002). Gordonia westfalica sp. nov., a novel rubber-degrading actinomycete. Int J Syst Evol Microbiol 52, 11331139.
Ludwig, W., Strunk, O., Westram, R., Richter, L., Meier, H., Yadhukumar, Buchner, A., Lai, T., Steppi, S. \& other authors (2004 ). ARB: a software environment for sequence data. Nucleic Acids Res 32, 1363-1371.

Luo, H., Gu, Q., Xie, J., Hu, C., Liu, Z. \& Huang, Y. (2007). Gordonia shandongensis sp. nov., isolated from soil in China. Int J Syst Evol Microbiol 57, 605-608.

Maldonado, L. A., Stainsby, F. M., Ward, A. C. \& Goodfellow, M. (2003). Gordonia sinesedis sp. nov., a novel soil isolate. Antonie van Leeuwenhoek 83, 75-80.

Minnikin, D. E., Alshamaony, L. \& Goodfellow, M. (1975). Differentiation of Mycobacterium, Nocardia, and related taxa by thin-layer chromatographic analysis of whole-organism methanolysates. J Gen Microbiol 88, 200-204.

Olsen, G. J., Matsuda, H., Hagström, R. \& Overbeek, R. (1994). fastDNAml: a tool for construction of phylogenetic trees of DNA sequences using maximum likelihood. Comput Appl Biosci 10, $41-48$.

Pruesse, E., Quast, C., Knittel, K., Fuchs, B. M., Ludwig, W., Peplies, J. \& Glöckner, F. O. (2007). SILVA: a comprehensive online resource for quality checked and aligned ribosomal RNA sequence data compatible with ARB. Nucleic Acids Res 35, 7188-7196.

Shen, F. T., Goodfellow, M., Jones, A. L., Chen, Y. P., Arun, A. B., Lai, W. A., Rekha, P. D. \& Young, C. C. (2006). Gordonia humi sp. nov., a novel actinomycete isolated from soil. Int J Syst Evol Microbiol 56, 2597-2601.

Soddell, J. A., Stainsby, F. M., Eales, K. L., Seviour, R. J. \& Goodfellow, M. (2006). Gordonia defluvii sp. nov., an actinomycete isolated from activated sludge foam. Int J Syst Evol Microbiol 56, 2265-2269.

Stackebrandt, E., Smida, J. \& Collins, M. D. (1988). Evidence of phylogenetic heterogeneity within the genus Rhodococcus: revival of the genus Gordona (Tsukamura). J Gen Appl Microbiol 34, 341348.

Stackebrandt, E., Rainey, F. A. \& Ward-Rainey, N. L. (1997). Proposal for a new hierarchic classification system, Actinobacteria classis nov. Int J Syst Bacteriol 47, 479-491.

Stolz, A., Busse, H.-J. \& Kämpfer, P. (2007). Pseudomonas knackmussii sp. nov. Int J Syst Evol Microbiol 57, 572-576.

Takeuchi, M. \& Hatano, K. (1998). Gordonia rhizosphera sp. nov. isolated from the mangrove rhizosphere. Int J Syst Bacteriol 48, 907912.

Tamura, K., Dudley, J., Nei, M. \& Kumar, S. (2007). MEGA4: molecular evolutionary genetics analysis (MEGA) software version 4.0. Mol Biol Evol 24, 1596-1599.

Tindall, B. J. (1990a). A comparative study of the lipid composition of Halobacterium saccharovorum from various sources. Syst Appl Microbiol 13, 128-130.

Tindall, B. J. (1990b). Lipid composition of Halobacterium lacusprofundi. FEMS Microbiol Lett 66, 199-202.

Tsukamura, M. (1971). Proposal of a new genus Gordona for slightly acid-fast organisms in sputum of patients with pulmonary disease and in soil. J Gen Microbiol 68, 15-26.

Xue, Y., Sun, X., Zhou, P., Liu, R., Liang, F. \& Ma, Y. (2003). Gordonia paraffinivorans sp. nov., a hydrocarbon-degrading actinomycete isolated from an oil-producing well. Int J Syst Evol Microbiol 53, 1643-1646.

Yassin, A. F., Shen, F. T., Hupfer, H., Arun, A. B., Lai, W. A., Rekha, P. D. \& Young, C. C. (2007). Gordonia malaquae sp. nov., isolated from sludge of a wastewater treatment plant. Int J Syst Evol Microbiol 57, 1065-1068. 
Yoon, J. H., Lee, J. J., Kang, S. S., Takeuchi, M., Shin, Y. K., Lee, S. T., Kang, K. H. \& Park, Y. H. (2000). Gordonia nitida sp. nov., a bacterium that degrades 3-ethylpyridine and 3-methylpyridine. Int J Syst Evol Microbiol 50, 1203-1210.

Zakrzewska-Czerwinska, J., Mordarski, M. \& Goodfellow, M. (1988). DNA base composition and homology values in the classification of some Rhodococcus species. J Gen Microbiol 134, 2807-2813.

Ziemke, F., Höfle, M. G., Lalucat, J. \& Rosselló-Mora, R. (1998). Reclassification of Shewanella putrefaciens Owen's genomic group II as Shewanella baltica sp. nov. Int J Syst Bacteriol 48, $179-186$. 